\title{
Fetichismo da desinformação na web: uma pandemia agravada
}

\author{
Rodrigo Silva Caxias de Sousa ${ }^{*}$ \\ Patricia Valerim ${ }^{* *}$ \\ Bruna Heller ${ }^{* * *}$ \\ Marcia Heloisa Tavares de Figueredo Lima ${ }^{* * * *}$
}

\section{Resumo}

Discute os conceitos de desinformação e práticas informacionais, aproximando-os da noção de semiformação cultural (semicultura), tendo como referência a Teoria Crítica da Informação e Comunicação. Defende que processos de comunicação ocorrem segundo práticas sociais de produção intencional de desinformação, segundo um circuito de produtividade que demanda do receptor/usuário a responsabilidade pela checagem das informações. Atenta para funções que se multiplicam e podem ser identificadas em relação a diferentes atores sociais, dentre os quais o Estado. Metodologicamente, trata-se de um estudo exploratório de abordagem qualitativa, através de uma triangulação metodológica, que consistiu em observação espontânea, seguida de análise de conteúdo e interpretação hermenêutica de um corpus de 86 fake news do site do Ministério da Saúde do Brasil. Os resultados permitiram a identificação de seis categorias emergidas da pré-análise. Na fase pos-

* Doutor em Comunicação e Informação pela Universidade Federal do Rio Grande do Sul. Professor permanente do Programa de Pós-Graduação em Ciência da Informação (PPGCIN/UFRGS). Professor adjunto III do Departamento de Ciência da Informação da Universidade Federal do Rio Grande do Sul (UFRGS). E-mail: rodrigo.caxias@ufrgs.br

** Mestranda do Programa de Pós-Graduação em Ciência da Informação da Universidade Federal do Rio Grande do Sul (PPGCIN/UFRGS). E-mail: patricia.valerim@gmail.com *** Mestranda do Programa de Pós-Graduação em Ciência da Informação da Universidade Federal do Rio Grande do Sul (PPGCIN/UFRGS). E-mail: brunahellerbh@gmail.com **** Doutora em Ciência da Informação pelo convênio Universidade Federal do Rio de Janeiro/Instituto Brasileiro de Informação em Ciência e Tecnologia. Professora permanente do Programa de Pós-Graduação em Ciência da Informação (PPGCIN/UFRGS). Professora adjunto I do Departamento de Ciência da Informação da Universidade Federal do Rio Grande do Sul (UFRGS). E-mail: marciahelolima@gmail.com 
terior, foram analisadas cinco notícias, considerando-se a identificação de aspectos operacionais e situacionais do governo em relação à disponibilização do conteúdo no site, relacionados às perspectivas ideológicas e religiosas que, supostamente, entram em contradição com o propósito de esclarecimento dos cidadãos sobre a pandemia. Concernente às cinco fake news analisadas, é prudente afirmar que o governo brasileiro se valeu do site do Ministério da Saúde para desinformar e violar o direito à informação.

Palavras-chave: Desinformação. COVID-19. Semicultura. Teoria Crítica da Informação e Comunicação. Práticas informacionais.

\section{D isisinformation's fetishism on the web: worsened pandemic}

Abstract

It discusses the concepts of disinformation and informational practices, bringing them closer to the notion of semiculture, having as reference the Critical Theory of Information and Communication. It argues that communication processes occur according to social practices of intentional production of disinformation, according to a productivity circuit that demands from the receiver/user, the responsibility for checking the information. Alert to functions that multiply and can be identified in relation to different social actors, including the State. Methodologically, it is an exploratory study with a qualitative approach, through a methodological triangulation, which consisted of spontaneous observation, followed by content analysis and hermeneutical interpretation of a corpus of 86 fake news from the website of the Ministry of Health of Brazil. The results allowed the identification of six categories that emerged from the pre-analyzes. In the subsequent phase, five news items were analyzed, considering the identification of operational and situational aspects of the government in relation to the availability of content on the website, related to ideological and religious perspectives that, supposedly, contradict the purpose of clarifying citizens about the pandemic. Concerning the five fake news analized, it is prudent to 
state that the Brazilian government used the Ministry of Health's website to disinform and violate information rights.

Keywords: Disinformation. COVID-19. Semiculture. Critical Theory of Information and Communication. Informational practices.

\section{Fetichismo de la desinformación en la web: una pandemia agravada}

Resumen

Se discuten los conceptos de desinformación y prácticas informativas, acercándolos a la noción de semicultura, teniendo como referencia la Teoría Crítica de la Información y la Comunicación. Sostiene que los procesos de comunicación ocurren según prácticas sociales de producción intencional de desinformación, de acuerdo con un circuito de productividad que demanda del receptor/usuario la responsabilidad de verificar la información. Atentos a funciones que se multiplican y pueden identificarse en relación con diferentes actores sociales, incluido el Estado. Metodológicamente, se trata de un estudio exploratorio con abordaje cualitativo, mediante una triangulación metodológica, que consistió en observación espontánea, seguida de análisis de contenido e interpretación hermenéutica de un corpus de 86 noticias falsas del sitio web del Ministerio de Salud de Brasil. A partir de los resultados fue posible identificar seis categorías que surgieron del preanálisis. En la fase posterior, se analizaron cinco noticias, considerando la identificación de aspectos operativos y situacionales del gobierno con relación a la disponibilidad de contenido en el sitio web, relacionados con perspectivas ideológicas y religiosas que, supuestamente, contradicen el propósito de esclarecer a la ciudadanía sobre la pandemia. En referencia a las cinco fake news analizadas, es prudente señalar que el gobierno brasileño utilizó el sitio web del Ministerio de Salud para desinformar y violar el derecho a la información.

Palabras clave: Desinformación. COVID-19. Semicultura. Teoría crítica de la información y la comunicación. Prácticas informativas. 


\section{Preparando o olhar para o problema}

O título deste artigo parafraseia um texto clássico da Teoria Crítica, intitulado "O Fetichismo na música e a regressão da audição" (Adorno, 1991). Nesse texto, o autor aponta para a instrumentalização das interpretações estéticas, advindas das racionalidades engendradas a partir da indústria cultural em relação ao empobrecimento do gosto musical, em virtude da incorporação da dinâmica de produtividade capitalista ao processo de formação cultural dos indivíduos. Esses processos semiformativos são articulados de distintas maneiras, a partir dos aparatos tecnológicos que incidem sobre a sociedade, conformando práticas sociais no cotidiano do mundo da vida (Habermas, 1984; 1997).

De forma análoga, neste estudo, problematizamos o quanto práticas (informacionais) de desinformação contribuem para a edificação de processos semiformativos, considerando a pauperização da informação como uma das novas égides conformadoras do capitalismo cognitivo. Essa discussão aponta para a conjuntura na qual ocorre uma escolha político-informacional, em que a categoria informação é relativizada, tendo como marco desconstrutivo a retomada da polarização política em escala global. Habermas apontava, em 1961, a relevância histórica da discussão de informações sobre a coisa pública em uma esfera pública que emergiu na Modernidade como fator fundamental para a construção das democracias ocidentais. E percebia, naquele início de década, os riscos, que se confirmariam, da oligopolização dos meios de comunicação de massa. Nos anos 2000 vemos a discussão de uma esfera pública mediatizada pelas plataformas eletrônicas. 0 que já era percebido como problema, agora está ampliado para um contingente de produtores anônimos com todos os riscos de produção e reprodução "espraiada" de informação não validada. Não mais oligopólios de informação ao modo empresarial, mas uma rede disforme de nós de informação. 
Ao depararmo-nos com a danificação e ruptura das formas de produção simbólica de informações, buscamos compreender que o uso indiscriminado de (des)informação com o propósito de manipular e distorcer a opinião pública torna-se estratégia preponderante. Como consequência, entram em risco a democracia, as mais honestas práticas informacionais e amplia-se o abismo informacional, que se torna um dos determinantes do alto número de mortes, tendo Brasil e EUA como exemplos nefastos da prática de disseminação de fake news (Kakutani, 2018) por diferentes agentes/atores sociais, dentro os quais os estamentos de primeiro escalão do Estado.

Especificamente em relação à pandemia e a COVID-19 (Ricard, Medeiros, 2020), podem ser observadas práticas informacionais de desinformação (Wardle, 2017; 2019; Wardle, Derakhshan, 2017) estabelecidas a partir da superestrutura estatal.

Grande dificuldade há em verificar-se a veracidade e precisão das informações neste período pandêmico, conforme relatam Mesquita et al. (2020), já que a desinformação se espalhou pelo mundo desde os primeiros casos do novo vírus. Nossa discussão está aqui estruturada a partir de uma contribuição que busca imbricar conceitos da Teoria Crítica da Informação aos estudos de práticas informacionais. Neste sentido, é necessário avisar ao leitor a empreitada teórica anunciada. A desinformação compreendida como produto cultural reificado ${ }^{1}$ se conforma como categoria central.

1 Reificação origina-se da palavra latim res e significa coisa. Literalmente, significa "objetificação" ou "coisificação". O sentido positivo de reificação é usado quando conceitos abstratos são transformados em objetos de estudo na Filosofia, mormente, mas também nas Ciências Sociais. 0 conceito está sendo empregado aqui em um sentido crítico marxista, de um processo inerente às sociedades capitalistas que sobrevalorizam a produção de "coisas", em detrimento das relações humanas e sociais, podendo ocasionar a perda da subjetividade, da autonomia e da autoconsciência ao atribuir ao ser humano uma natureza instrumental característica das mercadorias. 
Uma análise assim proposta requer que possamos compreender que a fetichização da desinformação, em especial das fake news, consiste tanto na depreciação dos conteúdos, da linguagem adotada, dos elementos retóricos e argumentos de composição das mensagens, quanto na projeção de exacerbado sobrevalor às notícias.

É imprescindível que se tenha uma ação imediata dos governos frente à pandemia, visto que as autoridades de saúde pública necessitam "buscar meios para combater o impacto que as informações falsas estão causando, com vistas a perdurar até mesmo quando a pandemia da COVID-19 terminar" (Fachin, Araújo, Souza, 2020, p. 3).

Segundo González de Gómez (1999), em quaisquer sistemas de informação realizam-se "ações de informação", todas, desde os primeiros processos, marcadas pelo seu "caráter seletivo". A mais evidente, e primeira destas ações, é a chamada "seleção" propriamente dita. Mas o caráter seletivo não é só o ponto de partida do movimento processual daquilo que vai ser recebido e entendido como informação em uma base de dados, um arquivo, um portal. 0 caráter seletivo instaura e constitui todas as demais fases do processo (qual descritor usar e qual a melhor expressão de busca são exemplos das sucessivas seleções nos processos que permitem o tratamento e a recuperação da informação nos diferentes sistemas de recuperação da informação). De modo análogo, ao analisarmos não só a recuperação, mas a produção de conteúdos para publicação em páginas da web, podemos afirmar que as fake news consolidam-se através de processos em que a desinformação é intencionalmente selecionada e disponibilizada, caracterizando-se, no entanto, como uma patologia social (Targino; Cavalcante, 2020).

Como forma de confrontar discussões teóricas com manifestações concretas identificadas na web, realizamos a análise hermenêutica de fake news sobre COVID-19. A análise das notícias 
disponibilizadas e checadas pela equipe técnica do Ministério da Saúde do Brasil em meio à pandemia são o foco do estudo. Os resultados deste artigo são parte de um estudo exploratório-descritivo em razão de um estranhamento relativo ao conflito de interesses de ordem política e religiosa, identificados dentre as notícias que compuseram o material empírico do estudo, tendo em vista a discrepância entre as temáticas identificadas no site do ministério e o propósito do canal de comunicação.

\section{Práticas sociais de desinf ormação e semicultura}

A compreensão das fake news como manifestações inusitadas de desinformação acena para possibilidades de interpretações em relação a distintos fenômenos sociais. A discussão conceitual deste estudo está assim proposta: inicialmente destacamos os conceitos de práticas informacionais e desinformação. 0 logro da proposta, ao buscar aporte na Teoria Crítica da Informação e Comunicação, posteriormente, os aproxima do conceito de semiformação cultural (semicultura). A convergência de tais conceitos denota a necessidade de discussões em relação à conjuntura de produção, uso e compartilhamento de informações falsas do ponto de vista de sua legitimidade em quaisquer locus (Ciência ou a esfera pública), na qual um circuito de produtividade de desinformações caracteriza-se por ações engendradas por diferentes atores e agentes sociais. A necessidade de informação verdadeira e fidedigna é condição sine qua non para a vida boa aristotélica, em quaisquer esferas da vida humana, seja ela privada (individual), seja pública (social). Para Araújo (2017, p. 221)

[..] práticas informacionais constitui-se num movimento constante de capturar as disposições sociais, coletivas (os significados socialmente partilhados do que é informação, do que é sentir necessidade de informação, de quais são as fontes ou recursos adequados) e também as elaborações e perspectivas individuais de como se relacionar com a infor- 
mação (a aceitação ou não das regras sociais, a negociação das necessidades de informação, o reconhecimento de uma ou outra fonte de informação como legítima, correta, atual), num permanente tensionamento entre as duas dimensões, percebendo como uma constitui a outra e vice-versa.

A perspectiva acima apontada é fundamental para a construção democrática, seja pelos movimentos diastólicos entre indivíduo, coletividade e sociedade; seja pela legitimidade e correção das informações produzidas e compartilhadas na sociedade.

Considerando esses aspectos nos valemos do conceito de práticas informacionais proposto por Savolainen (2008), que as compreende como os mecanismos que os indivíduos usam para promover seus empreendimentos cotidianos, baseando-se essencialmente em seus estoques de conhecimento como ponto de partida para a produção e compartilhamento de informações e são postas em movimento nas interações entre atores sociais, condicionados por aspectos advindos e reverberados na estrutura social.

Essas práticas informacionais são, como já o dissemos, seletivas e fundamentadas em processos de composição de conteúdos e inclusão, em quaisquer contatos sociais, mormente na construção de páginas na web ou portais ministeriais que são ofertados ao acesso público que deveriam pautar-se pelo cumprimento da obrigação de informar do Estado,

A fórmula "direito à informação verídica sobre os acontecimentos públicos" defendida também por Carvalho (1994) encontra apoio teórico em Kant desde 1795, em Habermas (1997) que vê o Direito como força integradora e em Hannah Arendt, na leitura de Celso Lafer (1991), para quem a informação verdadeira tem força estabilizadora na Política, sobretudo nas democracias. (Lima, 2013, p. 16).

Entretanto, merecem destaque as formas alternativas de depreciação da informação, dos conteúdos e dos processos de co- 
municação, "as fake news não se constituindo apenas um erro jornalístico [...]. Elas têm um elemento adicional: a intenção de enganar, e enganar com um propósito específico. Fake news são a mentira intencional a serviço de alguma escusa" (Pinheiro, 2019, p. 88). Neste sentido, as fake news configuram-se como a versão contemporânea da prática da mentira e do segredo (Bobbio, 1996; Arendt, 1999), categorias analíticas adotadas por Lafer (1991) como contrárias ao direito à informação. As práticas da mentira e do segredo obliteram o "juízo" (categoria de Arendt) e as possibilidades de agir comunicativo no mundo da vida (Habermas, 1992), ambos fundamentais para o exercício de uma racionalidade emancipatória e em busca de compreensões que, pautadas na ética, se apresentam de forma comprometida. Neste sentido,

Hoje sabemos que nossa mente não é especialmente talhada para se comportar de maneira racional. Somos levados espontaneamente a todo tipo de falácia lógica em nosso pensamento: conclusões indevidas, crença na autoridade e, acima de tudo, viés de confirmação. Se acreditamos em algo, nossa mente trabalha dobrado para valorizar informações que confirmem essa crença e invalidar informações que a contradigam. (Pinheiro, 2019, p. 90).

Outro aspecto comprometedor está relacionado à produção excessiva de informações, a hiperinformação, em virtude do abismo informacional advindo da impossibilidade de acesso e compreensão dos conteúdos, fruto de interesses ideológicos (Targino, Cavalcante, 2020) que fundamentam e comprometem a ética balizadora dos processos de comunicação.

Aspecto de não menos importância, diz respeito à atmosfera de fetichismo atribuída à categoria desinformação. Isso, porque a desinformação se articula atualmente como cerne de processos comunicativos depauperados. A exacerbação do valor à desinformação, implica em práticas condicionadas pelo uso de dis- 
tintas linguagens, recursos hipermidiáticos, artifícios retóricos, dentre outros aspectos. Como mencionado no preâmbulo de nossas discussões, valemo-nos da noção de desinformação, interpretando tal conceito segundo a perspectiva trazida por Floridi (2010), Fallis (2015), Wardle (2017; 2019), que a percebem como "engano intencional, informação imprecisa que pode enganar as pessoas".

É importante considerar que, conforme mencionam Ripoll e Matos (2020), no inglês existe uma subdivisão dos conceitos de desinformação. Os autores Floridi e Fallis consideram apenas a disinformation como o conceito que abarca a informação imprecisa com a intenção de enganar, diferente dos termos misinformation e mislead, conforme os autores explicam abaixo (Ripoll, Matos, 2020):

É importante perceber que a palavra 'desinformação', em português, muitas vezes é usada enquanto a tradução tanto de 'disinformation', como de 'misinformation', duas palavras que são conceitualmente distintas na língua inglesa. Conforme menciona Fallis (2010), ambas remetem ao contexto da informação imprecisa/incorreta (innacurate) e enganosa/ ilusória (misleading). No entanto, misinformation corresponde a um engano originado na fonte emissora de forma não proposital (honest mistake), enquanto que na palavra disinformation existe uma intenção consciente da fonte em enganar (intended to deceive). 0 autor comenta que, sendo assim, é mais difícil identificar uma disinformation, já que ela é justamente produzida com a intenção de não ser identificada como tal. (Ripoll, Matos, 2020, p. 97).

Diferentemente é necessário compreender vieses distintivos em relação às perspectivas que consideram a produção da informação segundo intencionalidades excusas subjacentes. Neste trabalho, a desinformação será assumida como atitudes subjetivas ou coletivas pautadas em ações que intencionam a pauperização do ato de informar, conforme evidenciam Ripoll e Matos 
(2020). Ademais, Starbird, Arif e Wilson (2019) compartilham da perspectiva de que a desinformação se caracteriza como um conjunto de operações estratégicas que visa estabelecer formas de manipulação nos ambientes online.

As operações de informação estratégica, e em particular a desinformação, funcionam para minar a integridade do espaço de informação e reduzir a agência humana, sobrecarregando nossa capacidade de dar sentido às informações. Elas, portanto, atingem o âmago de nossos valores. E elas afetam coisas que nos importamos sobre, por exemplo, encontrar informações que salvam vidas durante um evento de crise, organização online para mudança política e proteção dos espaços online contra intimidação e assédio. (Starbird, Arif, Wilson, 2019, p. 20:2, tradução nossa).

A desinformação e as fake news, muitas vezes, são compreendidas como construtos simplistas de informação que visam o engano a algum receptor, mas assumem um escopo mais amplo ao representar algo que os próprios indivíduos fazem cotidianamente (Starbird, Arif, Wilson, 2019). 0 fenômeno se caracteriza através de dinâmicas e produtos pautados em racionalidades instrumentais, que se articulam ao mundo da vida (Habermas, 1984), como a manipulação calculista (Starbird, Arif, Wilson, 2019), em razão do uso das tecnologias da informação como forma deliberada e proposital de confundir a opinião pública (Kakutani, 2018), característica fundamental da pós-verdade.

A chamada "era da pós-verdade", com todos os cuidados e provisoriedade da noção, trata-se de uma conjuntura em que fatos importam menos do que a opinião pública (D'Ancona, 2018), uma vez que há uma forte tendência em acreditar naquilo que catalisa reações sentimentais e emotivas em relação às pessoas. Decorre desta perspectiva o sucesso das fake news como uma forte arma para a desinformação: geralmente envolvem um contexto em que se opõem bem ou mal, direita ou esquerda, entre outros contrastes. 
Encontramo-nos diante de um impasse ético a ser desvelado, em razão de que o "[...] projeto ideológico subjacente ao avanço das fake news ameaça o significado da ética da informação 2.0 junto ao imaginário social. Assim, é imprescindível enfrentá-lo como fenômeno social" (Targino, Cavalcante, 2020, p. 33). Para que possamos avaliar o quanto o poder e as implicações das fake news são compreendidas sobre a perspectiva adotada, podemos pensar como Starbird, Arif e Wilson (2019, p. 20:4), que enfatizam que a "desinformação é menos sobre o valor de verdade de uma ou mais informações e mais sobre como essas peças se encaixam para servir a um propósito específico" (tradução nossa).

Especificamente em relação ao tema deste estudo, as fake news elencadas no site do Ministério da Saúde, é necessário enfatizar que essas manifestações de hiperinformação articulam composições de conteúdos que interseccionam política, religião e ideologia.

Defendemos o argumento de que a conjuntura articulada a partir da pandemia demonstra que o governo brasileiro (ou parte dele) optou por ações que se pautaram na racionalidade instrumental da desinformação. 0 predomínio de uma racionalidade instrumental estruturou-se em razão de questões políticas que se propagam na sociedade, estabelecendo práticas informacionais "confusionantes" (Sfez, 1992; 1996) em cadeia a partir de um governo que engendra articulações que ora apresenta declarações fundamentadas no cuidado das populações embasadas no saber científico, ora disponibiliza fake news (inverdades), ora desmente-as, e outras vezes ainda onera o cidadão/leitor/usuário no confronto com outras fontes para a validação de informações. É possível refletir também que há fortes indícios de quebra de hierarquia e empoderamentos pessoais nos estamentos inferiores da burocracia.

Isso ocorre em razão de que as práticas informacionais se encontram imbricadas à lógica do capital, perdendo importância a 
informação diante dos subprodutos oriundos dos processos de desinformação e imprimindo à conjuntura da pandemia a sensação de desordem informacional (Wardle, 2017; 2019).

Nesse contexto de desinformação surge a noção de infodemia, termo que foi cunhado pela Organização Mundial de Saúde (OMS) para categorizar o excesso de informações que dificultam o acesso a orientações sobre a COVID-19, compreendida como uma dentre outras formas de desinformação (Organização Pan-Americana de Saúde, 2020). Essa produção concomitante de informação e desinformação por parte de um mesmo emissor sobre a doença e a pandemia gera um ambiente de incertezas e um terreno fértil para a manipulação da informação com intenções duvidosas. Poderíamos destacar, como Bobbio (1996), que se forma um subgoverno. A suplementaridade de termos relativos às distintas formas de desinformação tem se consagrado através da relativização da noção de verdade. A pertinência no que se refere a discussões sobre a pauperização dos processos comunicativos e na composição de informações falsas remete, na atualidade, a ideia de pós-verdade como

sinónimo de mentira emotiva, esto es, la distorsión deliberada de la realidad con el fin de crear y modelar la opinión pública e influir en las actitudes sociales. Una realidad en la que los hechos objetivos, las referencias fácticas, tienen menos influencia que las apelaciones a las emociones y a las creencias personales. (Olmo y Romero, 2019, n.p.).

Na mesma obra "Mudança estrutural da esfera pública”, Habermas já afirmava em 1961 que, na contemporaneidade, a verdade é dependente da validação de argumentos racionais na esfera pública. Como consequência de circuito de ações informacionais seletivas que geram produtos ofertados para serem recebidos e reconhecidos como informação, é propagada uma cultura na qual as formações discursivas, já desvinculadas das referências éticas inquestionáveis das culturas tradicionais, encontram e 
ancoram sua aura de acreditação na autoridade científica, ao mesmo tempo que se pactuam na esfera da Política como acordos. Neste contexto, a validação e o caráter de verdade da informação passam a depender 1) de seu confronto com o saber legitimado pela Ciência e 2) da pluralidade de fontes de informações utilizadas pelo receptor/usuário/cidadão. A produção e divulgação deliberada de fake news, de acordo com uma racionalidade instrumental, quebra o frágil sistema de crenças na ordem de uma racionalidade democrática e claramente viola o direito do cidadão de receber informações fidedignas e confiáveis do Estado, que tem, por sua vez, a obrigação de informar (Seelaender, 1991). Lembremos que Giddens (1991) afirmava que a confiança é uma das categorias basilares para o funcionamento do Estado contemporâneo. 0 homem contemporâneo precisa confiar que outros seres humanos obedecerão a leis elementares de trânsito, por exemplo, até para atravessar a rua. Sem esta confiança prévia, de que outros seres humanos cumprirão as mesmas leis que obrigam a todos, não há por que sair à rua de modo pacífico.

0 argumento de autoridade é uma falácia notória, mas é dele que dependemos para que a vida em sociedade funcione. Confiamos nos cientistas, nos professores universitários, nos jornalistas, nos institutos públicos. Essa crença nas autoridades é racional. Temos bons motivos para acreditar na ciência, no jornalismo etc. Eles existem num mundo que erros de um são explorados por seus rivais, gerando um incentivo virtuoso. Seguem um método científico que poderia ser reproduzido, trabalham segundo balizas e códigos de éticas profissionais que filtram os equívocos mais grosseiros; são transparentes e estão abertos a críticas. Mesmo assim, se alguém estiver decidido a acreditar que as principais instituições da sociedade estão unidas num megacomplô para enganar sistematicamente o cidadão comum, não há como provar de maneira definitiva que ela está errada. Um certo ato de fé - ou melhor, de confiança - é necessário. (Pinheiro, 2019, p. 92-93). 
Essa confiança necessária à manutenção do contrato social advém, conjugada como outros fatores, da crença na forma republicana do Estado moderno no qual a verdade se pactua e se estabelece com base em justificadas proposições ofertadas à discussão pública. Não há uma verdade a priori. A confiança advém da crença em um "nós" que, aqui reunidos, construímos a verdade que se postula publicamente sob crivos da razoabilidade a que todos concordamos nos submeter, sobretudo quanto à crença em um modelo de Estado cujos dirigentes são eleitos. Dizendo de outra forma, a validação dessas informações requer que ampliações sejam realizadas no que se refere às formas de interpretação de conteúdos quer na web, quer nas relações off-line no mundo da vida. Isso, porque o mencionado circuito calcado no trinômio produtividade-checagem-validação compromete as possibilidades e interpretações acerca de entendimento de informações que circulam na esfera pública. Há uma inversão ética, uma quebra cínica da obrigação de informar do Estado.

Produto dessa inversão ética que, na atualidade, de forma contumaz, relativiza o cerne dos processos de comunicação, a desinformação consubstancia a conformação do que pode ser compreendido como semiformação cultural. A semiformação implica na formação do indivíduo por meio da estandardização da cultura, na qual bens simbólicos têm esvaídas sua aura e essência cultural, em razão da incorporação da lógica do mercado aos processos que os efetivam. Diante desse empobrecimento a informação e as práticas informacionais são transformadas pela lógica semicultural em meras mercadorias. Assim, os produtos da semicultura servirão de conteúdo formativo para a sociedade de massa. Este processo formativo denomina-se "semiformação" (Iop, 2009, p. 21).

Tal conceito está em contraposição à busca de entendimento entre os atores sociais, sendo a racionalidade emancipatória referência que alicerça a formação cultural amplamente discutida pela Teoria Crítica como alternativa de libertação dos indivídu- 
os. Neste sentido, as trocas infocomunicacionais são discutidas em nosso domínio e Araújo (2009) afirma

[...] que orientações marxistas se fundamentam na Ciência da Informação a partir de contribuições oriundas da Teoria Crítica da Informação. Isso ocorre em virtude de considerações ao "[...] conflito, a desigualdade, o embate de interesses (grifo nosso) em torno da questão da informação - e para tanto, buscará explicar os fenômenos a partir de sua historicidade (Araújo, 2009, p. 197).

Como destaca o autor, é do tensionamento entre distintos interesses relacionados à informação que emerge as possibilidades de concretização dos processos emancipatórios e o entendimento entre os atores/agentes sociais sobre os atos comunicativos. O embate de interesses desvelado a partir da produção, uso e compartilhamento de informações se materializa em subprodutos de informação, em razão de que a suplementação argumentativa de tais embates se edifica no âmbito das práticas sociais.

Isso, porque

Toda prática social é uma prática informacional (grifo nosso) - expressão esta que se refere aos mecanismos mediante os quais os significados, símbolos e signos culturais são transmitidos, assimilados ou rejeitados pelas ações e representações dos sujeitos sociais em seus espaços instituídos e concretos de realização (Marteleto, 1995, p. 92).

Alves (2019), no mesmo sentido, articula que com a desinformação coloca-se em risco a autonomia dos sujeitos, embora a liberdade de informação, e consequentemente o direito à informação, esteja categoricamente defendida no artigo 5ำ da Constituição Brasileira de 1988, incisos XIV e XXXIII, assim como em todo um conjunto de normas supranacionais representado pelas convenções e acordos dos quais o Brasil foi signatário (Cepik, 2000). 
0 cidadão tem um direito-crédito de ser informado pelo Estado com informações verdadeiras e mais do que o superado direito a ser informado pela simples comunicação de fatos. 0 "direito ao fato" envolveria um direito-crédito à explicação, no sentido de que seja necessária uma permanente "tradução" da complexificada gestão tecnocrática do Estado contemporâneo, tornando-se inteligíveis ao homem comum (Seelaender, 1991). Em relação às contribuições superestruturais, o Estado tem a obrigação positiva de informar e minimizar a circulação de desinformações, o que requer um conjunto de ações práticas que objetive a emancipação informacional, o fácil acesso de informações, políticas públicas de combate à desinformação, entre outros. Em meio à pandemia da COVID-19, todos esses aspectos (ou a despeito de que saibamos deles) têm sido utilizados pelos disseminadores de fake news, direcionando o foco das notícias para interesses circundantes à doença. Isso, porque as pessoas no mundo da vida encontram-se influenciadas por ambições e tensionamentos que as conduzem a formas de comportamento padronizado de forma instrumental.

A checagem da informação se caracteriza como o conjunto de procedimentos que busca analisar a qualidade e veracidade de informações, de acordo com distintas práticas sociais. Atualmente encontramo-nos diante da ampliação e de uma nova ordem não apenas relativa às atribuições, mas, sobretudo, aos atores sociais que as efetivam, visto que a verificação da desinformação se consagra como cerne de uma lógica comunicativa que pauta a desinformação.

Isso implica que a produção, compartilhamento e validação da informação se concretize como procedimentos efetivados por sujeitos, instituições e o governo. Targino e Cavalcante (2020), a esse respeito, são categóricos ao afirmar que o combate de parcela do poder governamental às inverdades em diferentes esferas concretiza-se como contribuição merecedora de aprovação uma vez que, pelo menos aparentemente, contribui para 
processos formativos que visam o esclarecimento das coletividades quanto ao rechaço à circulação de desinformações e aos seus produtores, haja vista que ações de controle e classificação normativa sobre a veracidade da informação emergem tanto no cenário do jornalismo quanto no da ciência (Oliveira, Quinan, Toth, 2020) como verdadeiras práticas de contrainformação.

Consideradas as questões desenvolvidas neste estudo, destacamos que as decisões metodológicas realizadas em meio ao processo exploratório encontram-se apresentadas no tópico subsequente.

\section{A triangulação metodológica}

Estudo exploratório-descritivo, de abordagem qualitativa, que analisou as fake news sobre a COVID-19 checadas e disponibilizadas no site Saúde sem Fake News do Ministério da Saúde do Brasil, entre os meses de janeiro a junho de 2020.

Inicialmente realizamos buscas sobre fake news relacionadas à COVID-19 na web. Dentre os sites e plataformas de redes sociais observados, chegamos à webpage www.saude.gov.br, intitulada "Saúde Sem Fake News", que compõe o site do Ministério da Saúde. Deste modo, foi tomada a decisão de considerar as notícias sobre COVID-19 arroladas no site do Ministério entre os dias 15 de abril e 31 de julho de 2020, compreendendo a importância do órgão em relação ao esclarecimento e orientação ao cidadão.

A investigação é derivada de um estudo mais amplo que analisou um corpus inicial constituído de 86 fake news. Fazemos referência ao corpus maior, com o objetivo de evidenciar de forma panorâmica as primeiras análises, identificando e mensurando palavras dos títulos das 86 fake news. Baseado em triangulação metodológica, nos valemos das técnicas de observação espontânea (Gil, 1999), combinada à análise de conteúdo (Bardin, 2016) e interpretação hermenêutica (Gadamer, 2007). Em razão de tal combinação, a 
obtenção, a organização e a análise dos dados foram compostas a partir de fases complementares. Esse procedimento foi realizado através do uso do Software $\mathrm{R}$, desconsiderando as seguintes expressões "novo coronavírus" e "coronavírus" (stopwords), devido à recorrência dos termos na maioria das notícias.

A organização dos dados ocorreu através da composição de um quadro com a inserção do conjunto dos 79 hiperlinks das notícias em um editor de texto. Na sequência, foi realizada a inserção no quadro da imagem correspondente a cada hiperlink para, de forma visual, facilitar o início do processo de análise. Posteriormente, no mês de junho, foram incorporadas mais sete notícias, sendo a última com data de 08 de junho de 2020.

Em meio a esse processo, identificamos a retirada da notícia (Figura 4) relativa ao uso da Cloroquina, além de uma diminuição considerável de publicações de notícias. A partir disso, incluímos no processo metodológico a realização do acesso ao site do Ministério da Saúde duas vezes por semana, para verificar a continuidade de publicações de novas notícias. Mediante à realização da leitura flutuante (Bardin, 2016) uma planilha do Software Excel 2013 foi criada, como forma de permitir o detalhamento das análises em relação às peculiaridades e características comuns entre as notícias. Considerando que neste estudo as decisões metodológicas são produtos de fases que se sucedem e que balizam decisões posteriores, desse corpus maior foram escolhidas para análise hermenêutica cinco fake news, considerando-se a identificação de aspectos operacionais e situacionais do governo em relação à disponibilização do conteúdo no site, relacionados às perspectivas ideológicas e religiosas que, supostamente, entram em contradição com o propósito de esclarecimento dos cidadãos sobre a pandemia.

Decorrente dos processos de análise e da releitura das notícias emergiram categorias do fenômeno, que se encontram destacadas no Quadro 1. 
Quadro 1 - Categorias emergidas do corpus das 86 notícias

\begin{tabular}{|c|c|}
\hline $\begin{array}{c}\text { Categorias } \\
\text { Emergidas/ } \\
\text { Descrição }\end{array}$ & Subcategorias/Descrição \\
\hline $\begin{array}{l}\text { Temática prin- } \\
\quad \text { cipal } \\
\text { (Referente aos } \\
\text { assuntos iden- } \\
\text { tificados nas } \\
\text { notícias) }\end{array}$ & $\begin{array}{l}\text { CD - Causas da doença - Notícias que indicam fatores supostamente } \\
\text { responsáveis por terem originado a doença. } \\
\text { CP - Cura ou prevenção - Notícias relativas à cura ou prevenção re- } \\
\text { lacionadas à COVID-19. } \\
\text { DE - Danos ou efeitos - Notícias que indicam possíveis sequelas da } \\
\text { doença. } \\
\text { DM - Declarações do Ministro da Saúde - Notícias sobre pronun- } \\
\text { ciamentos dos ministros a respeito da pandemia. } \\
\text { FD - Fatos ou dados - Notícias que relatam acontecimentos ou mos- } \\
\text { tram dados relacionados à pandemia no Brasil e no mundo. } \\
\text { RC - Riscos ou formas de contágio - Notícias que apontam possí- } \\
\text { veis fatores ou atitudes que fazem com que as pessoas sejam conta- } \\
\text { minadas pelo vírus que ocasiona a COVID-19. }\end{array}$ \\
\hline $\begin{array}{c}\text { Linguagem } \\
\text { adotada } \\
\text { (Maneira de } \\
\text { apresentar a } \\
\text { ideia da notícia) }\end{array}$ & $\begin{array}{l}\text { FO - Formal - Pautada no uso culto de expressões em consonância } \\
\text { às normas gramaticais. } \\
\text { IN - Informal - Pautada no uso expressões do cotidiano, de uma for- } \\
\text { ma espontânea, quando não há rigor às normas gramaticais. } \\
\text { ND - Não disponível - Quando a notícia não foi disponibilizada pelo } \\
\text { Ministério da Saúde. } \\
\text { VIS - Visual - Pautada em elementos imagéticos, independentemen- } \\
\text { te da adequação às normas gramaticais. }\end{array}$ \\
\hline $\begin{array}{l}\text { Elementos de } \\
\text { composição da } \\
\text { notícia } \\
\text { (Recursos } \\
\text { midiáticos que } \\
\text { compunham a } \\
\text { notícia) }\end{array}$ & $\begin{array}{l}\text { AU - Áudio - Recurso sonoro para gravar, transmitir e reproduzir } \\
\text { uma mensagem passível de ser ouvida por uma pessoa. } \\
\text { EM - Emojis - Símbolos que representam uma emoção, ideia, palavra } \\
\text { ou frase completa. Geralmente utilizados em conversas instantâneas } \\
\text { via dispositivos móveis. } \\
\text { IMF - Imagem/ Foto - Signos não verbais que utilizam componentes } \\
\text { visuais para transmitir uma ideia. } \\
\text { LI - Link - Endereço de um site, documento (ou um recurso) na web } \\
\text { (Internet). } \\
\text { ND - Não disponível - Quando a notícia não foi disponibilizada pelo } \\
\text { Ministério da Saúde. } \\
\text { TE - Texto - Conjunto de palavras que transmite uma ideia. } \\
\text { VID - Vídeo - Imagem em movimento que pode ser acompanhada } \\
\text { de som e texto. }\end{array}$ \\
\hline
\end{tabular}




\begin{tabular}{|c|c|}
\hline $\begin{array}{l}\text { Categorias } \\
\text { Emergidas/ } \\
\text { Descrição }\end{array}$ & Subcategorias/Descrição \\
\hline $\begin{array}{l}\text { Artifícios retó- } \\
\text { ricos } \\
\text { (Forma como } \\
\text { são compostos } \\
\text { os argumentos } \\
\text { das notícias) }\end{array}$ & $\begin{array}{l}\text { AL - Alarmista - Utiliza-se explicitamente de argumentos que am- } \\
\text { pliam a proporção da notícia, que podem causar medo ou inquie- } \\
\text { tação. } \\
\text { JO - Jornalístico - Utiliza-se de argumentos característicos da lin- } \\
\text { guagem jornalística. } \\
\text { NI - Não identificado - Quando não foi possível identificar o artifício } \\
\text { retórico adotado na notícia. } \\
\text { PU - Publicitário - Utiliza-se de argumentos com a intenção de per- } \\
\text { suadir em relação a produtos ou ideias. } \\
\text { RE - Reducionista - Utiliza-se explicitamente recursos que minimi- } \\
\text { zam ou instrumentalizam o assunto noticiado. } \\
\text { SA - Satírico - Utiliza-se de argumentos humorísticos e sarcásticos } \\
\text { como a intenção de criticar costumes, instituições ou hábitos. } \\
\text { SE - Sensacionalista - Utiliza de recursos em que há intenção de } \\
\text { causar impacto, de chocar a opinião pública, procura dar destaque } \\
\text { de importância ou de urgência a uma notícia. }\end{array}$ \\
\hline $\begin{array}{c}\text { Artifícios de } \\
\text { atribuição de } \\
\text { credibilidade à } \\
\text { notícia } \\
\text { (Relações que } \\
\text { buscam validar } \\
\text { o conteúdo) }\end{array}$ & $\begin{array}{l}\text { AI - Autoridade Institucional - menções a organizações que têm } \\
\text { competência técnica, científica ou política. Compreendem também } \\
\text { fontes informacionais como jornais e periódicos científicos. } \\
\text { AP - Autoridade Pessoal - menções a indivíduos que possuem um } \\
\text { título que confere competência técnica ou científica. } \\
\text { NA - Não se aplica - quando a notícia não menciona nenhuma forma } \\
\text { de atribuição de credibilidade à notícia. } \\
\text { ND - Não disponível - Quando a notícia não foi disponibilizada pelo } \\
\text { Ministério da Saúde. }\end{array}$ \\
\hline $\begin{array}{c}\text { Procedimento } \\
\text { de checagem } \\
\text { da notícia } \\
\text { (Maneira pela } \\
\text { qual a notícia é } \\
\text { reinterpretada } \\
\text { no que se refere } \\
\text { ao uso de fontes } \\
\text { e argumentos, } \\
\text { possibilitando } \\
\text { que a informa- } \\
\text { ção seja valida- } \\
\text { da pelo leitor) }\end{array}$ & $\begin{array}{l}\text { EX - Excluído - Quando excluída a totalidade do conteúdo da che- } \\
\text { cagem. } \\
\text { FU - Fundamentado - Composto por argumentos validados a partir } \\
\text { da menção explícita a fontes de informação nas quais podem ser en- } \\
\text { contradas informações adicionais, possibilitando o cidadão chegar } \\
\text { a mesma conclusão de classificação da notícia como falsa ou verda- } \\
\text { deira. } \\
\text { NF - Não Fundamentado - Composto de forma instrumental, em } \\
\text { que os argumentos não são conclusivos e quando não há conteúdos } \\
\text { de fontes adicionais que validem o argumento estabelecido. }\end{array}$ \\
\hline
\end{tabular}

Fonte: elaborado pelos autores. 
O critério de categorização empregado para a composição das categorias e subcategorias foi o semântico (Bardin, 2016), emergido com base no conteúdo explícito identificado em cada notícia. Ainda que o quadro acima seja produto de um percurso metodológico, merece destaque que optamos por apresentá-lo, tendo em vista que se materializa como resultado da leitura flutuante e da pré-análise do material.

\section{Análise das notícias}

Nesta seção são apresentadas inicialmente interpretações resultantes da observação espontânea, da leitura flutuante e da pré-análise. Tendo a intenção de explorar e elucidar o fenômeno, explicitamos um panorama concernente a 86 fake news, arrolando informações relacionadas às temáticas e à periodicidade das publicações disponibilizadas no site do Ministério da Saúde. Em uma segunda fase realizamos a análise hermenêutica das cinco fake news.

As temáticas estão representadas através da nuvem de palavras, que ilustra a incidência dos assuntos relativos ao corpus das 86 notícias. A ilustração evidencia uma preponderância de conteúdos relativos à cura ou à prevenção da doença, mais especificamente relacionados à ingestão de alimentos naturais, bebidas e substâncias supostamente imunológicas, tendo em vista que estes temas ocupam posição central na Figura 1. 
Figura 1 - Nuvem palavras obtidas a partir dos títulos das 86 Fake News

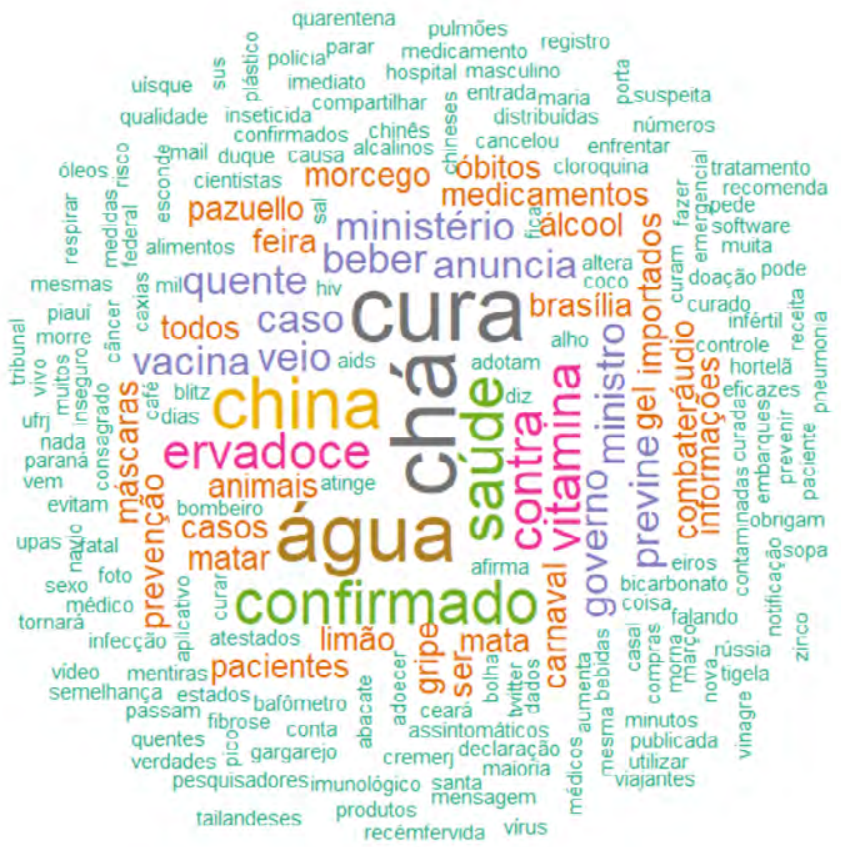

Fonte: Dados da pesquisa (2020).

Em menor incidência, localizados à margem da ilustração (termos com fonte menor em tom azul claro), há uma pluralidade de tópicos pontuais sobre a pandemia. Entremeado aos assuntos de maior incidência e de menor incidência, ou seja, adjacente à parte central da nuvem de palavras, podemos observar referências ao governo, ao ministério, a ministros (grifos nossos) e a outros elementos circunscritos ao cenário pandêmico.

De forma convergente às temáticas obtidas pela nuvem de palavras, apresentamos os temas emergidos da análise do corpus das notícias por ordem de maior para menor incidência: cura ou prevenção, dados sobre a pandemia, riscos ou formas de contágio, causas da COVID-19, declarações de ministros, danos ou efeitos da doença. 
Após elencarmos as temáticas das fake news disponibilizadas no site, mereceu atenção o fato de que, na medida em que o número de contágio e mortes por COVID-19 aumentava no País, a quantidade de notícias checadas pelo ministério diminuía significativamente. Causa um estranhamento a projeção de que a população tenha parado de encaminhar as fake news para serem checadas pelo corpo de servidores do ministério, não somente referente à COVID-19, mas também de qualquer outro tema relacionado à saúde, visto que, enquanto isso, a situação da pandemia e da infodemia se agravavam no País, leva-se ainda em consideração que em 2020, no período de janeiro a junho, especificamente a respeito de coronavírus, totalizaram 86 notícias postadas e distribuídas conforme Quadro 2:

Quadro 2 - Incidências das notícias em diferentes mandatos dos ministros da saúde

\begin{tabular}{|l|c|c|c|c|c|c|c|}
\hline Ministro & Jan. & Fev. & Mar. & Abr. & Maio & Jun. & Total \\
\hline Mandetta & 16 & 28 & 27 & 6 & - & - & $\mathbf{7 7}$ \\
\hline Teich & - & - & - & 6 & - & - & $\mathbf{6}$ \\
\hline Pazuello & - & - & - & - & 2 & 1 & $\mathbf{3}$ \\
\hline Total & $\mathbf{1 6}$ & $\mathbf{2 8}$ & $\mathbf{2 7}$ & $\mathbf{1 2}$ & $\mathbf{2}$ & $\mathbf{1}$ & $\mathbf{8 6}$ \\
\hline
\end{tabular}

Fonte: elaborado pelos autores (2020).

Vale destacar que depois de junho, somente no dia 17 de julho, uma nova notícia com temática sobre a COVID-19 foi publicada, com elementos de apresentação completamente distintos do padrão que vinha sendo adotado pelo site, não havendo mais nenhuma publicação de notícia, mesmo que de outros temas sobre saúde, até o término das análises aqui efetuadas, no dia 15 de setembro de 2020.

Ainda sobre essas evidências, ressaltamos que o período em que houve diminuição no número de notícias verificadas pelo governo, conforme pode ser observado no Gráfico 1, coincidiu com as trocas ministeriais que ocorreram entre 16 de abril (saída do ministro Luiz Henrique Mandetta), a substituição pelo ministro Nelson Teich, que permaneceu apenas 30 dias no cargo (até 15 de maio), e a posse do ministro interino Eduardo Pazuello (militar). É necessário enfatizar que essas trocas ministeriais ocor- 
reram fundamentalmente em razão de divergências entre os ministros e o presidente, tendo em vista que o presidente Bolsonaro defendeu abertamente a alteração no protocolo do sistema de saúde para uso indiscriminado da cloroquina em tratamento preventivo contra a COVID-19.

A interpretação da possibilidade de haver relação entre as trocas ministeriais e diminuição do número de notícias verificadas pelo site pode se valer do que Starbird, Arif e Wilson (2019) chamam de operações estratégias de informação, que se constituem em ações que visam a manipulação da sociedade, entre elas a de viés político. Destacamos ainda que o período em que ocorreu a publicação do maior número de notícias checadas sobre a pandemia foi na gestão do ministro Mandetta, circunscrita à indicação da necessidade de realização do distanciamento social no Brasil, por volta do dia 16 de março.

Gráfico 1 - Incidências de notícias verificadas pelo Ministério da Saúde

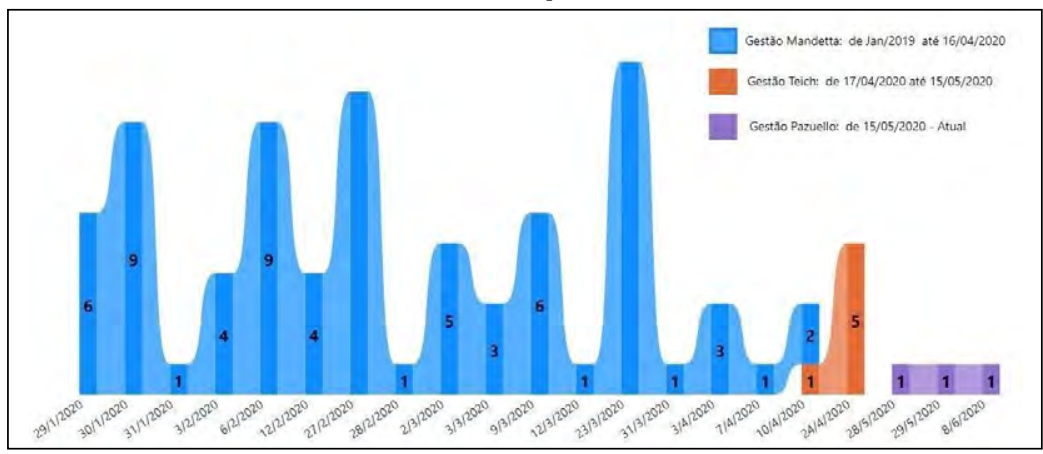

Fonte: Elaborado pelos autores (2020).

A respeito da diminuição da publicação de notícias checadas, desde a última troca ministerial, que compreende a saída do ministro Teich e o ingresso no ministério do ministro Pazuello, ocorrida em maio de 2020, as grandes corporações midiáticas noticiaram a redução da transparência de dados sobre a COVID-19 por parte do governo brasileiro, no qual temos o seguinte destaque: 
Em meio ao avanço dramático da epidemia do coronavírus no país, Ministério da Saúde passa a dar menos destaque a números de mortes e casos. Atrasos e ênfase em dados "positivos" se tornaram rotina na pasta. [...] adotou uma abordagem "otimista" em relação aos efeitos da pandemia, dando ênfase ao número de recuperados. A divulgação dos boletins com os mortos e contaminados, por sua vez, desapareceu das redes sociais da pasta. (Struck, 2020, s.p.).

As análises acima nos permitiram observar contradições no que se refere ao uso do site para fins que não caracterizam o seu propósito, corroborando a lógica governamental que se vale de distintos canais de comunicação para incitar disputas ideológicas e político-partidárias em torno da pandemia, além de causar desinformação pela ausência de centralização de informações. Para Han (2017, p. 21) "A política é uma agir estratégico. Já por causa disso lhe é própria uma esfera oculta. Uma total transparência iria paralisá-la”.

Em sequência à apresentação dos aspectos que englobam uma perspectiva mais ampla observada no fenômeno, partimos para a apresentação do resultado das análises referente às cinco notícias que versam sobre peculiaridades referentes ao governo, a perspectivas ideológicas e religiosas que orbitam no contexto pandêmico e na produção de fatos alternativos ${ }^{2}$ que não necessariamente estão relacionados à COVID-19. É preciso destacar que as interpretações hermenêuticas consideraram as categorizações apresentadas na metodologia deste estudo para a composição das devidas análises.

Entremeio ao corpus das fake news contabilizamos quatro matérias, nas quais, supostamente, os interlocutores da mensagem eram os ministros da saúde. Para além de esclarecer a população

2 Fatos alternativos foram mencionados por Kellyanne Conway, assessora do presidente norte-americano Donald Trump, para explicar que a realidade individual se trata de "fatos alternativos", ou seja, a forma como cada um interpreta os fatos (D’Ancona, 2018). 
sobre assuntos atrelados à COVID-19, percebemos que houve uma intencionalidade do ministério em relação à escolha de notícias que envolveram declarações de ministros. Essa ação evidencia uma operacionalização dos canais oficiais para garantir uma espécie de blindagem em relação às decisões, discursos e práticas informacionais do governo. De acordo com estudo de Ricard e Medeiros (2020), para validar essa estratégia, diferentes formas de desinformação foram utilizadas pelo governo brasileiro para liderar uma cruzada contra recomendações científicas e baseadas em evidências.

Na Figura 2, elencamos a composição de duas notícias que aparentam apresentar conteúdos semelhantes, mas que, no entanto, utilizam recursos distintos. A imagem da esquerda é uma combinação de áudio com a imagem do ministro Mandetta, e a imagem à direita utiliza uma composição de texto e áudio, sendo que na parte textual observamos o uso de uma linguagem informal para comunicar a mensagem. Tal variação engendra reflexões no sentido de que os operadores estratégicos (Starbird, Arif, Wilson, 2020) articulam diferentes recursos para viralizar a desinformação, proporcionando um maior alcance das fake news.

Figura 2 - Fake news sobre declarações do Ministro da Saúde
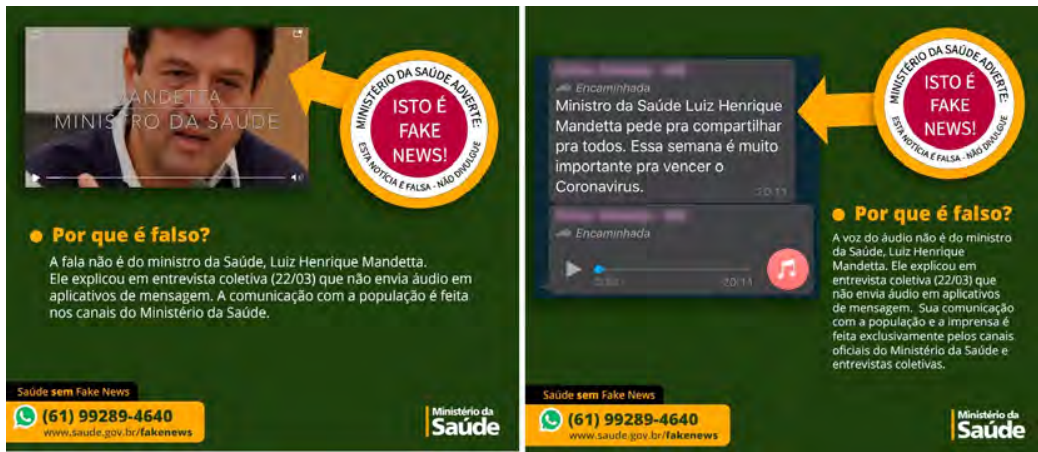

Fonte: Ministério da Saúde (2020). 
Com base no propósito do site do ministério, que é verificar a veracidade de notícias que apresentam características de fake news, relacionadas ao tema de saúde e que circulam nas redes sociais, chama atenção o fato de que, duas das três fake news publicadas na gestão Pazuello, conforme Gráfico 1, referem-se à desmentir declarações que teriam sido proferidas pelo próprio ministro interino Eduardo Pazuello. Uma das notícias intitulada "Mensagem do Pazuello no Twitter sobre Polícia Federal", conforme Figura 3, sequer faz menção à pandemia.

Figura 3 - Mensagem do Pazuello no Twitter sobre Polícia Federal

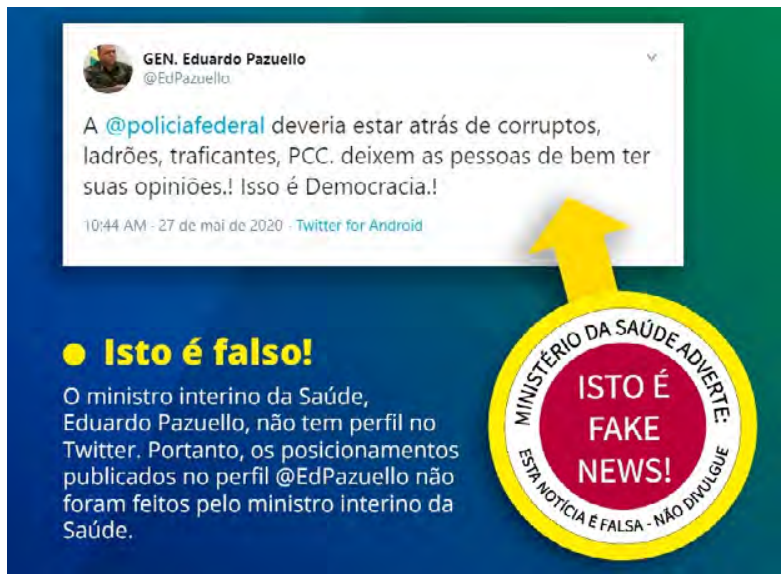

Fonte: Ministério da Saúde (2020).

Através do uso da linguagem informal, a notícia é elaborada a partir de uma mensagem publicada em um suposto perfil no Twitter do ministro Eduardo Pazuello. Observamos na fake news, o uso do recurso retórico alarmista, estruturado de forma que pode ser identificado no texto, incitações que transmitem uma sensação de inquietude e temor, indicando que a polícia federal estaria tolhendo a ação/opinião dos cidadãos ("pessoas de bem") em detrimento à escória da sociedade ("corruptos, ladrões, traficantes, PCC"). Tal escolha de composição da fake news remete-nos à polarização entre os que deveriam ter direito 
de voz na sociedade e os que não deveriam ter. Esse dualismo (os bons e os maus) parece reforçar o argumento utilizado nas fake news, ao ter a intenção de suscitar que o "fato" noticiado ameaçaria a democracia.

Ademais, na notícia veiculada através de um perfil de rede social, verificamos a combinação de diferentes elementos como texto, imagem e link “@policiafederal”, que Ripoll e Matos (2020) ressaltam serem características presentes nos formatos de desinformação, pois assumem diversas formas de transmissão em adequação às tecnologias e dinâmicas de comunicação que permeiam a sociedade. Entendemos que essa menção a um perfil institucional tem como intenção credibilizar e validar o conteúdo.

A publicação dessa notícia no site do ministério evidencia novamente uma reação por parte do governo no sentido de desmentir um suposto posicionamento do ministro. Causa estranheza essa priorização de temática de ordem política tratada como uma questão religiosa e uma discrepância em relação ao propósito do site que é o de informar, etimologicamente, pôr em forma, colocar ordem no caos. 0 propósito de um site construído por agentes do Estado é, também, ou principalmente, garantir a governamentalidade (Foucault, 1979). Esse uso indevido da máquina estatal, por parte do governo, demonstra a incorporação de uma racionalidade instrumental nas práticas informacionais, nas quais as intencionalidades e fins de caráter ideológico preponderam em relação à publicação e aos esclarecimentos sobre desinformação relativos à pandemia que eventualmente circularam nas mídias vindas de outras fontes geradoras, jamais de um órgão com autoridade. Uma das consequências da veiculação e do reconhecimento de fake news originadas de dentro da máquina pública é a sensação de desgoverno, ou subgoverno na expressão de Bobbio.

Correlacionado aos aspectos apresentados até aqui, constatamos que uma das notícias selecionada para este estudo foi posteriormente excluída do site do ministério, Figura 4. 
Figura 4 - Notícia excluída do site do Ministério da Saúde

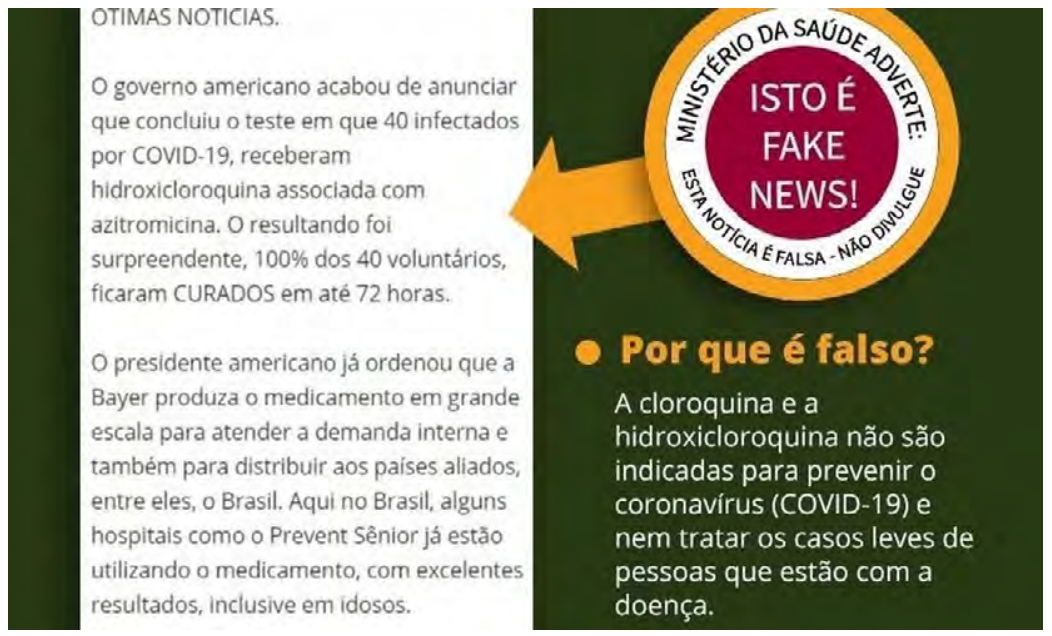

Fonte: Ministério da Saúde (2020).

A notícia foi classificada como falsa (fake news) e havia sido publicada com o título "Cloroquina e hidroxicloroquina passam a ser usadas no Brasil para combater coronavírus". 0 procedimento de exclusão mereceu destaque na Revista Época, enfatizando que, instantes antes de realizar sua supressão, o governo federal anunciou seu posicionamento quanto à ampliação da possibilidade de uso da substância contra a COVID-19 (Amado, 2020). Além desse detalhe, posteriormente o Ministério da Saúde expediu, no final de junho de 2020, um Ofício Circular direcionado à Fundação Oswaldo Cruz, solicitando ampla divulgação do tratamento precoce com cloroquina. Este acontecimento foi divulgado pelas grandes corporações midiáticas como uma forma do governo federal usar da credibilidade da instituição de pesquisa para promover a medicação, mesmo diante da decisão da Organização Mundial de Saúde (OMS) em suspender os testes com a droga, visto que não houvera resultados positivos quanto à sua eficácia no tratamento ou prevenção da doença. Ainda corroborando com a politização evidenciada em torno da medicação, contamos com a seguinte contribuição: 
[...] os debates sobre a cloroquina se distribuem a partir de um conjunto discursivo em torno de um processo de polarização política e politização da ciência atrelada à descrença sobre as instituições epistêmicas em que os sujeitos transparecem a incerteza inerente da ciência e põem em dúvida a existência de consenso científico em prol de vieses ideológicos e político-partidários (Araújo, Oliveira, 2020, n.p.).

Seguindo nessa linha ideológica, outro fator que pode ter ocasionado a decisão pela exclusão da fake news do site do Ministério da Saúde é que o texto faz menções ao governo norte-americano, que é aliado estratégico do atual governo brasileiro, no qual, segundo Severo e Feres (2020, p. 11), “a política externa do Brasil é, segundo o próprio governo, de alinhamento automático com os Estados Unidos".

Por fim, a interseccionalidade entre religião e saúde também se materializa como prática efetivada nas notícias. É possível identificar na Figura 5 uma composição que contempla disposições estratégicas de diversos elementos, tanto textuais quanto visuais, resultando em uma estética que se assemelha a um cartaz, e que se utiliza do recurso retórico publicitário, com o intuito de persuadir pessoas a participarem de um evento milagroso que segue a lógica da espetacularização. Tal espetáculo é representado através da combinação de diversas imagens: (i) cena bíblica (calvário); (ii) um homem com dedo em riste que passa uma ideia de poder, de alguém prepotente e ditatorial; (iii) uma mulher com braços abertos segurando um microfone, assemelhando-se a uma postura artística/musical; e (iv) a imagem do próprio coronavírus, que recebe este nome por sua forma redonda cercada por uma espécie de coroa. 
Figura 5 - Fake news - 0 poder de Deus contra o coronavírus

\section{CORONAVÍRUS}

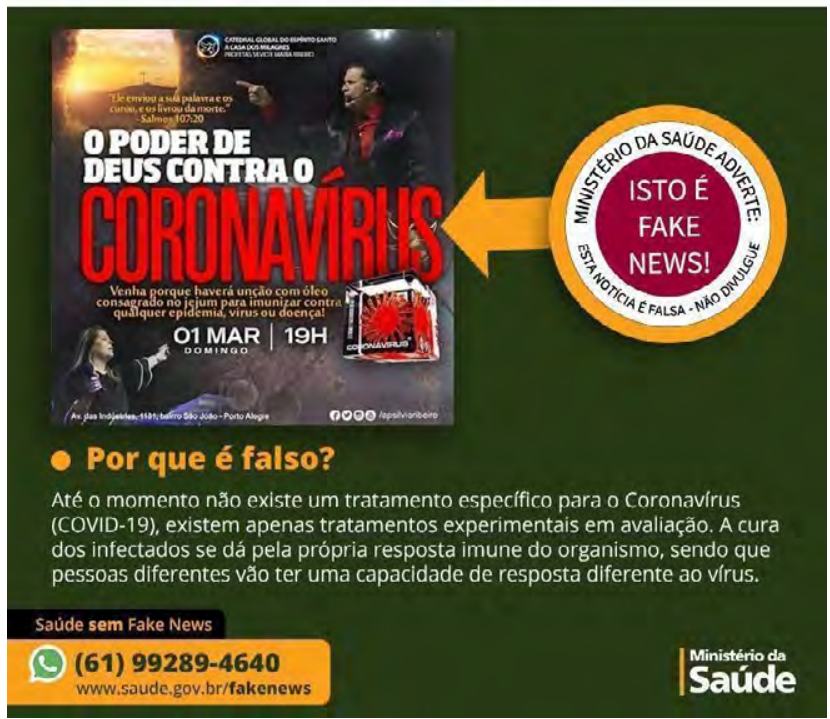

Fonte: Ministério da Saúde (2020).

Somado a esses elementos, ainda observamos a adoção de linguagem informal, ao fazer menção a seguinte expressão: "Venha porque haverá unção com óleo consagrado no jejum para imunizar contra qualquer pandemia, vírus ou doença!". Outro elemento textual utilizado para compor o emaranhado de informação combinada com as imagens já descritas é a citação de uma passagem bíblica: "Ele enviou sua palavra e os curou, e os livrou da morte" - 'Salmo 107:20'”. Tal citação da obra sagrada, embora seja apresentada com uma fonte em tamanho menor, tenta conferir crédito ao evento, e transmite a mensagem de que supostamente através da fé as pessoas encontrariam a cura para a doença.

No que diz respeito ao procedimento de checagem da notícia por parte do Ministério da Saúde, o procedimento não foi fundamentado, visto que embora a equipe técnica tenha verificado a infor- 
mação, bem como atribuído a ela o selo de fake news, observamos um certo descuido no momento da elaboração do texto que fundamenta a classificação do conteúdo. Em nenhum momento o texto faz menção ao evento religioso, tampouco alerta para os riscos das pessoas se guiarem somente pela crença para tratar a doença, leva-se em consideração o quanto simplificações dessa natureza podem comprometer a compreensão da população a respeito da gravidade da pandemia.

Ademais, em nossa análise, identificamos que a mesma resposta foi usada para justificar a falsidade de diversas outras notícias, que diziam respeito a outros eventos corriqueiros do cenário pandêmico, demonstrando um desleixo, ao não desenvolver um texto específico relacionado ao tema da fake news. Kakutani (2018, p. 10) corrobora ao dizer que "o descaso pelos fatos, a substituição da razão pela emoção, e a corrosão da linguagem estão diminuindo o valor da verdade". Dito de outro modo, o texto elaborado pela equipe técnica é bastante padronizado, como pode ser observado a seguir:

Não compartilhe esse conteúdo, ele é falso! Até o momento não existe um tratamento específico para o Coronavírus (COVID-19), existem apenas tratamentos experimentais em avaliação. A cura dos infectados se dá pela própria resposta imune do organismo, sendo que pessoas diferentes vão ter uma capacidade de resposta diferente ao vírus. Algumas pessoas não chegam a desenvolver sintomas, enquanto outras progridem para uma infecção grave e fatal. 0 tratamento médico dos casos visa fornecer suporte para os pacientes caso formas graves, com a administração de oxigênio por exemplo, ou tratamento para complicações que possam ocorrer, além de terapia sintomática para alívio de febre e mal estar. As recomendações de prevenção para o coronavírus (COVID-19) são:

- Lave as mãos com frequência, com água e sabão. Ou então higienize com

- álcool em gel 70\%.

- Cubra seu nariz e boca com lenço ou COM O BRAÇO (e não com as 
- mãos!) quando tossir ou espirrar.

- Evite contato próximo com pessoas resfriadas ou que estejam com sintomas parecidos com os da gripe.

- Quando estiver doente, fique em casa.

- $\quad$ Evite tocar nos olhos, nariz e boca com as mãos não lavadas.

- Não compartilhe objetos de uso pessoal (como talheres, toalhas, pratos e copos).

- $\quad$ Evite aglomerações e mantenha os ambientes ventilados. Para saber mais sobre a doença, acesse: saude.gov.br/coronavirus. (BRASIL, 2020, n.p.).

A lógica de composição textual da fundamentação da checagem da fake news, que se eximiu de mencionar os rituais praticados no evento, no nosso entendimento, pode ter relação com o posicionamento ideológico e religioso do governo, principalmente personificado no presidente Jair Bolsonaro e destacado na ocasião da posse em relação à primeira dama. A esse respeito, trazemos o pensamento de Walter Benjamin (2013) que defende que a racionalidade do capital pode ser compreendida como uma espécie de religião, que não se restringe somente à esfera econômica, mas que transita por todos os campos da sociedade.

Finalmente, a proliferação das fake news em sua condição de patologias sociais da informação decorrentes de suas entranhas, a exemplo da desinformação, constitui preocupação global, tendo em vista que os discursos estão à mercê da vontade da verdade, em que "[...] a verdade se deslocou do ato ritualizado, eficaz e justo, de enunciação, para o próprio enunciado: para seu sentido, sua forma, seu objeto, sua relação e a sua referência" (Foucault, 1996, p. 15).

\section{Roendo Discursos}

Neste estudo compusemos um processo que buscou analisar, explorando inicialmente, a perspectiva panorâmica das fake news sobre COVID-19 arroladas no site do Ministério da Saúde do Brasil. 
Assumida essa empreitada, nos propusemos a aproximar conceitos advindos dos Estudos de Usuários de Informação a contribuições da Teoria Crítica da Informação e Comunicação. Para tanto, apresentamos os conceitos de práticas informacionais, desinformação e semiformação cultural (semicultura), os compreendendo como elementos constituintes, indiciais, mas reveladores da conjuntura de desinformação na qual estamos imersos em meio à pandemia. Em virtude dessas aproximações, defendemos que a sociedade brasileira, especialmente, se encontra diante de um dilema ético, em razão de que a publicização de informações tendenciosas se consagra como inusitado circuito de produtividade que reproduz a lógica do capitalismo.

O conteúdo transmutado em notícia é disseminado por meio de uma variedade de estratégias persuasivas, artifícios retóricos, recursos hipermídias combinados, envolvendo distintas temáticas, formas de apresentação e destaque, variado conjunto de signos linguísticos e imagéticos, referências a autoridades, dentre outros elementos que se constituem em marcas discursivas que conferem aparente credibilidade às notícias.

A triangulação metodológica permitiu detectar e descrever tais marcas que revelam que o Ministério da Saúde, para além de sua função maior como órgão de Estado que é de "elaboração de planos e políticas públicas voltados para a promoção, a prevenção e a assistência à saúde dos brasileiros" (Brasil, 2020), vem promovendo uma politização da doença, ao colocar em pauta conteúdos que são fruto de um tensionamento entre Ciência, Política, Economia e Religião, comprometendo o entendimento sobre a pandemia e o combate à crise sanitária.

Esse processo de desinformação intencional tem, também, nuances de complexidade, porque diferentes sujeitos agem e diferentes atores atuam na seleção e produção daquilo que virá a ser disponibilizado, oferecido e recebido como informação em razão da necessidade de esclarecer a população sobre a pandemia. 
Com as redes sociais online, essas informações tendem se alastrar ainda mais rapidamente. Esse ambiente faz referência a um enorme aumento de informações não confiáveis sobre o coronavírus, a pandemia, bem como engendra sua multiplicação exponencial e incontrolável. Mais uma vez recorrendo à metáfora da rede: é (quase) impossível desatar os nós da mentira de uma fake news.

Longe de qualquer dúvida, uma política desinformacional - modelada quer por racionalidade instrumental, quer por irracionalidade, quer por desrazão (por loucura ou maldade) exemplarmente demonstrada por práticas discursivas desinformacionais (e deformantes) - adoece a sociedade e a democracia, solapa a credibilidade nas autoridades políticas, arruína, enfim, os princípios éticos sobre os quais se pauta a representação dos poderes constituídos e as crenças no sistema democrático que tenta construir, há mais de três séculos, o sempre inacabado projeto da Modernidade. Valemo-nos de Foucault como guia crítico dos discursos da Modernidade e de Habermas como memória dos princípios que regem este processo inacabado.

Como forma de compreendermos os estranhos conteúdos entre fake news arroladas pelo governo brasileiro, optamos pela análise triangulada com recursos de três técnicas que, ao descrever, desvelam e revelam. E, face a esta análise qualitativa (sempre uma análise, porque está longe de ser a única e definitiva), os discursos onipotentes têm sua fragilidade revelada. Discurso em vários níveis: do factual ao supostamente factual; da mentira consciente ou subliminar, sempre veiculador de mitos. Nada mais fizemos do que descrever tais discursos em sua efemeridade de escrita de um tempo que há de passar, elevando-os à categoria de monumentos exemplares para a história de um discurso, no futuro. Os sujeitos desaparecem e os discursos onipotentes aparecem em seu lugar.

Encerramos este artigo parafraseando o autor anônimo da introdução de conhecido fascículo da Revista Tempo Brasileiro 
dedicada ao filósofo. Quem o escreveu? "Pouco importa!" - diria Foucault. Para este prefaciador anônimo, quanto às estruturas discursivas: "descrevê-las já é roê-las por dentro" (Apresentação, 1996, p. 13).

\section{Ref erências}

Adorno, T. W. 0 fetichismo na música e a regressão da audição. In: ADORNO, Theodor W; HORKHEIMER, Max. Textos escolhidos. 5. ed. São Paulo: Nova Cultural, 1991. (Coleção Os Pensadores, 16).

Teoria da semicultura. Rio de Janeiro: Zahar, 1966. Disponível em: $<$ https://www.marxists.org/portugues/adorno/ano/mes/teoria.htm>. Acesso em: 15 de ago. 2020.

Amado, Guilherme. Ministério da saúde apaga do site reportagem que chamava tratamento via cloroquina de "fake news.". 2020. Disponível em: <https://epoca.globo.com/guilherme-amado/ministerio-da-saude-apaga-do-site-reportagem-que-chamava-tratamento-via-cloroquina-de-fake-news-24437247 >. Acesso em: 12 de jun. 2020.

Apresentação. In: Foucault, M. et al. 0 homem e o discurso: a arqueologia de Michel Foucault. 2. ed. Rio de Janeiro: Tempo Brasileiro, 1996. (Comunicação, $3)$.

Araújo, R.; Oliveira, T. A Desinformação e mensagens sobre a hidroxicloroquina no Twitter. 2020. Disponível em: doi: 10.1590/SciELOPreprints.1113. Acesso em: 04 set. 2020.

Araújo, C. A. A. Correntes teóricas da ciência da informação. Ciência da informação, Brasília, v. 38, n. 3, Dec. 2009, p. 192-204. Disponível em: <http://www. scielo.br/scielo.php?script=sci_arttext\&pid=S0100-19652009000300013\&ln $\mathrm{g}=\mathrm{en} \& \mathrm{nrm}=\mathrm{iso}>$. Acesso em: 26 abr. 2020.

Araújo, C. A. A. 0 que são práticas informacionais? Revista Informação em Pauta, Fortaleza, v. 2, n. esp., out. 2017, p. 217-236.

Arendt, Hannah. Crises da república. São Paulo: Perspectiva, 1999, p. 9-48.

Bardin, L. Análise de conteúdo. 6. ed. São Paulo: Martins Fontes, 2016.

Benjamin, Walter. 0 capitalismo como religião. São Paulo: Boitempo, 2013.

Berti, I. C. L. W.; Araújo, C. A. V. A constituição de um regime de informação - os acontecimentos "carta de Temer a Dilma" e Marcela Temer: bela, recatada e 
do 'lar'”. Encontro Nacional de Pesquisa em Ciência da Informação, n. XIX ENANCIB, 2018. Disponível em: <http://hdl.handle.net/20.500.11959/brapci/103878>. Acesso em: 30 jul. 2020.

Bobbio, N. A democracia e o poder invisível. In: o Futuro da democracia. Rio de Janeiro: Paz e Terra, 1986. p. 83-106. (Pensamento crítico, 63).

Brasil. Ministério da Saúde. Óleo consagrado para curar coronavírus. Disponível em: <https://www.saude.gov.br/fakenews/46510-oleo-consagrado-para-curar-coronavirus-e-fake-news>. Acesso em: 12 jun. 2020.

Brasil. Ministério da Saúde. Institucional. Disponível em: <https://www.saude.gov.br/acesso-a-informacao/institucional>. Acesso em: 12 jun. 2020.

Bruno, F; Roque, T. A ponta de um iceberg de desconfiança. In: BARBOSA, Mariana (Org.). Pós-verdade e fake news: reflexões sobre a guerra de narrativas. Rio de Janeiro: Cobogó, 2019.

Cepik, M. Direito à informação: situação legal e desafios. Informática Pública, v. 2, n. 2, dez. 2000, p. 43-56.

D'ancona, M. Pós-verdade: a nova guerra contra os fatos em tempos de fake news. Barueri: Faro Editorial, 2018.

Esteves, J. P.; Escudero, R. C. E. O novo público da esfera pública e a reconceptualização do consenso como topos da comunicação pública. Comunicação Pública, [S.I.] v. 10, n. 17, 2015. Disponível em: <https://doi.org/10.4000/ cp.915>. Acesso em: 20 de set. 2020.

Fachin, J.; Araújo, N. C.; Sousa, J. C. Credibilidade de informações em tempos de COVID-19. Revista Interamericana de Bibliotecología, [S.l.], v. 43, n. 3., 2020. Disponível em: DOI: <10.17533/udea.rib.v43n3eRf3>. Acesso em: 20 de set. 2020.

Fallis, D. What is disinformation?. Library Trends, v. 63, n. 3, p. 401426, 2015. Disponível em: <https://www.ideals.illinois.edu/bitstream/ handle $/ 2142 / 89818 / 63.3$.fallis.pdf? sequence $=2>$. Acesso em: 06 jan. 2020 .

Floridi, L. Information: a very short introduction. Oxford: Oxford University Press, 2010.

Foucault, M. Arqueologia do saber. 5. ed. Rio de Janeiro: Forense Universitária, 1997.

Foucault, M. et al. $\mathbf{0}$ homem e o discurso: a arqueologia de Michel Foucault. 2. ed. Rio de Janeiro: Tempo Brasileiro, 1996.

Foucault, M. Microfísica do poder. 10. ed. Rio de Janeiro: Graal, 1979.

Foucault, M. A ordem do discurso. 3. ed. São Paulo: Loyola, 1996. 
Freitas, L. S. de. Sentidos da história e história dos sentidos da Ciência da Informação: um esboço arqueológico. Morpheus: Revista Eletrônica em Ciências Humanas. Rio de Janeiro, v. 2, n. 2, 2003. Disponível em: <http://www.seer. unirio.br/index.php/morpheus/article/view/4085>. Acesso em: 21 set. 2020.

Gadamer, H. Hermenêutica em retrospectiva: a virada hermenêutica. 2. ed. Petrópolis: Vozes; v.2, 2007.

Gatti, L. Exercícios do pensamento. Novos estudos - CEBRAP, 2009. Disponível em: <https://www.scielo.br/scielo.php?script=sci_arttext\&pid =S0101-33002009000300012>. Acesso em: 14 abr. 2020.

Giddens, A. As conseqüências da modernidade. São Paulo: Ed. Unesp, 1991. Gil, A. C. Métodos e técnicas de pesquisa social. 5. ed. São Paulo: Atlas, 1999. González De Gómez, M. N. O caráter seletivo das ações de informação. Informare, v. 5, n. 2, p. 7-31, 1999. Disponível em: <https://ridi.ibict.br/handle/123456789/126>. Acesso em: 20 set. 2020.

Habermas, J. Mudança estrutural da esfera pública. Rio de Janeiro: Tempo Brasileiro, 1984. 398 p. (Biblioteca Tempo Universitário, v. 76).

Habermas, J. Direito e democracia: entre facticidade e validade. Rio de Janeiro: Tempo Brasileiro, 1997. 2 v. (Biblioteca Tempo Universitário, v. 101-102).

Han, B. C. Sociedade da transparência. Petrópolis: Vozes, 2017.

Iop, E. Formação cultural, semicultura e indústria cultural: contribuições de Adorno sobre a emancipação. Revista Espaço Pedagógico, v. 16, n. 2, 27 jan. 2009. Disponível em: <https://doi.org/10.5335/rep.2013.2212>. Acesso em: 20 de set. 2020 .

Lima, M. H. T. F. O estatuto teórico epistemológico do direito à informação no contemporâneo: das dimensões aos limites. Tendências da Pesquisa Brasileira em Ciência da Informação, v. 7, n. 1, 2014. Disponível em: <http://hdl.handle. net/20.500.11959/brapci/119493>. Acesso em: 24 set. 2020.

Kakutani, M. A morte da verdade: notas sobre a mentira na era Trump. Rio de Janeiro: Intrínseca, 2018.

Lafer, C. A reconstrução dos direitos humanos: um diálogo com o pensamento de Hannah Arendt. São Paulo: Companhia das Letras, 1991. 406 p.

Machado, C. C. V. et. al. Ciência contaminada: analisando o contágio de desinformação sobre coronavírus via Youtube. S.l: Centro de Estudos e Pesquisas de Direito Sanitário, 2020. Disponível em: <http://napdisa.prp.usp.br/pt/ lancamento-do-estudo-ciencia-contaminada/ciencia-contaminada>. Acesso em: 08 jul. 2020. 
Marteleto, R. M. Cultura informacional: construindo o objeto informação pelo emprego dos conceitos de imaginário, instituição e campo social. Ciência da Informação, [S.l.], v. 24, n. 1, 1995. Disponível em: <http://revista.ibict.br/ ciinf/article/view/613/615>. Acesso em: 07 jul. 2020.

Mesquita, C. T. et al. Infodemia, Fake News and Medicine: Science and The Quest for Truth, 2020. Disponível em: <http://publicacoes.cardiol.br/portal/ijcs/ingles/aop/2020/AOP_editorial-fake-news_i.pdf>. Acesso em: 17 set. 2020 .

Oliveira, T.; Quinan, R.; Toth, J. Antivacina, fosfoetanolamina e Mineral Miracle Solution (MMS): mapeamento de fake sciences ligadas à saúde no Facebook. Revista Eletrônica de Comunicação, Informação e Inovação em Saúde, v. 14, n.1., 2020. Disponível em: <doi:https://doi.org/10.29397/reciis. v14i1.1988>. Acesso em: 12 jun. 2020.

Olmo Y Romero, J. A. A desinformacion: conceptos y perspectivas. 2019. Disponível em: <http://www.realinstitutoelcano.org/ wps / wcm / connect/ 3 ac 69 a 0 d- 5 b 29-4 b 12 - 8cf3 - af 3 c 5 ff 3 b 2 c b / ARI41-2019-OlmoRomero-Desinformacion-concepto-y-perspectivas. pdf?MOD=AJPERES\&CACHEID=3ac69a0d-5b29-4b12-8cf3-af3c5ff3b2cb $>$. Acesso em: 12 jun. 2020.

Organização Pan-Americana Da Saúde. Entenda a infodemia e a desinformação na luta contra a covid-19. [S.l]: OPAS/OMS, 2020. Disponível em: <https://iris.paho.org/bitstream/handle/10665.2/52054/Factsheet-Infodemic por.pdf?sequence=14>. Acesso em: 19 jun. 2020 .

Pinheiro, J. Fake news e o futuro da nossa civilização. In: BARBOSA, Mariana (Org.). Pós-verdade e fake news: reflexões sobre a guerra de narrativas. Rio de Janeiro, Cobogó, 2019, p. 87-95.

Pinto, J. M. De R. A teoria da ação comunicativa de Jürgen Habermas: conceitos básicos e possibilidades de aplicação à administração escolar. Paidéia, Ribeirão Preto. 1995, n.8-9, p.77-96. ISSN 0103-863X. Disponível em: <https://doi. org/10.1590/S0103-863X1995000100007>. Acesso em: 15 ago. 2020.

Pinto, F. V. M.; Araujo, C. A. A. Estudos de usuários: quais as diferenças entre os conceitos comportamento informacional e práticas informacionais? Ciência da Informação em revista, Maceió, v.6, n.3, set./dez. 2019, p. 15-33. Disponível em: <https://www.seer.ufal.br/index.php/cir/article/view/8037/0>. Acesso em: 15 ago. 2020.

Ricard, J.; Medeiros, J. Using misinformation as a political weapon: COVID-19 and Bolsonaro in Brazil, The Harvard Kennedy School (HKS) Misinformation Review, [S.l.], v. 1, n. 2., 2020. 
Ripoll, L.; Matos, J. C. O contexto informacional contemporâneo: o crescimento da desinformação e suas manifestações no ambiente digital. Inf. Prof., Londrina, v. 9, n. 1, jan./jun. 2020, p. 87-107. Disponível em: DOI: 10.5433/2317-4390.2020v9n1p87. Acesso em: 20 set. 2020.

Savolainen, R. Everyday information practices: a social phenomenological perspective. Plymouth: Scarecrow, 2008.

Savolainen, R. Information behavior and information practice: reviewing the "umbrella concepts" of information seeking studies. Library quarterly, [S.l.], v. 77, n. 2, april 2007, p. 109-132. Disponível em: <https://www.jstor.org/ stable/10.1086/517840?seq=1>. Acesso em: 16 ago. 2020.

Savolainen, R. Modeling the interplay of information seeking and information sharing: a conceptual analysis. Aslib Journal of Information Management, [S.l.], v. 71, n. 4, 2019, p. 518-534. Disponível em: <https://www.emerald.com/insight/ content/doi/10.1108/AJIM-10-2018-0266/full/html>. Acesso em: 15 ago. 2020.

Seelaender, A. 0 direito de ser informado: base do paradigma moderno do direito de informação. Revista de Direito Público, v. 25, n. 99, jul./set. 1991, p. 147-159.

Severo, C. C. W.; Feres, C. P. da C. O Brasil e o mundo: impactos do governo Bolsonaro e da Covid-19. Espirales. [S.l], jun. 2020. Disponível em: <https:// revistas.unila.edu.br/espirales/issue/view/147>. Acesso em: 21 set. 2020.

Sfez, L. A Comunicação. Lisboa: Instituto Piaget, [1992?]. 156 p. (Epistemologia e sociedade, 26).

Sfez, L. Informação, saber, comunicação. Informare, Rio de Janeiro, v. 2, n. 1, jan./jun. 1996, p. 5-13.

Silva, J. L. C. Pós-verdade e informação: múltiplas concepções e configurações. Encontro Nacional de Pesquisa em Ciência da Informação, n. XIX ENANCIB, 2018. Disponível em: <http://hdl.handle.net/20.500.11959/brapci/103784>. Acesso em: 04 ago. 2020.

Spinney, L. In Congo, fighting a virus and a groundswell of fake news. Science, v. 363, n. 6424, jan. 2019, p. 213-214. Disponível em: <http://science.sciencemag.org/content/363/6424/213>. Acesso em: 8 jan. 2020.

Silva, J. L. C. Pós-verdade e informação: múltiplas concepções e configurações. Encontro Nacional de Pesquisa em Ciência da Informação, n. XIX ENANCIB, 2018. Disponível em: <http://hdl.handle.net/20.500.11959/brapci/103784>. Acesso em: 04 ago. 2020.

Starbird, K.; Arif, A.; Wilson, T. Disinformation as collaborative work: surfacing the participatory nature of strategic information operations. PACM Journal 
Name, v. X, n. CSCW, Article Z, 2019. Disponível em: <https://faculty.washington.edu/kstarbi/Disinformation-as-Collaborative-Work-Authors-Version. pdf $>$. Acesso em: 16 set. 2020.

Struck, J. Como o governo vem reduzindo a transparência de dados sobre a covid-19. DW, 2020. Disponível em: <https://p.dw.com/p/3dJcp>. Acesso em: 19 jun. de 2020.

Wardle, C. Disinformation Gets Worse. 2017. Disponível em: <https://www. niemanlab.org/2017/12/disinformation-gets-worse>. Acesso em: 22 set. 2020.

Targino, M. Das G.; Cavalcante, A. V. B. Admirável mundo novo da ética da informação 2.0 em tempos de fake news. Informação em Pauta, Fortaleza, v. 5, n. 1, jan./jun. 2020, p. 33-53. Disponível em: <https://doi.org/10.36517/25253468.ip.v5i1.2020.43238.33-53>. Acesso em: 19 jun. 2020.

Wardle, C. Understanding information disorder. EUA: First Draft, 2019. e-book. Disponível em: <https://firstdraftnews.org/wp-content/uploads/2019/10/Information_Disorder_Digital_AW.pdf?x76701>. Acesso em: 18 fev. 2020.

Wardle, C.; Derakhshan, H. Information disorder: Toward an interdisciplinary framework for research and policy making. [S.l.]: [s.n.], 2017. e-book. Disponível em: <https://shorensteincenter.org/wp-content/uploads/2017/10/ PREMS-162317-GBR-2018-Report-de\%CC\%81sinformation.pdf>. Acesso em: 01 mar. 2020.

Recebido em 30/10/2020

Aprovado em 01/12/2020 